\title{
Survey of Bioluminescent Coleoptera in the Atlantic Rain Forest of Serra da Paranapiacaba in São Paulo State (Brazil)
}

\author{
Raphael M. Santos ${ }^{1}$, Marcelo Nivert Schlindwein ${ }^{2}$ \& Vadim R. Viviani ${ }^{1,3}$ \\ ${ }^{1}$ Universidade Federal de São Carlos, Departamento de Física, Química e Matemática, \\ Sorocaba, SP, Brazil. \\ ${ }^{2}$ Universidade Federal de São Carlos, Departamento de Biologia, Sorocaba, SP, Brazil. \\ ${ }^{3}$ Corresponding author: Vadim R. Viviani, e-mail: viviani@ufscar.br
}

SANTOS, R.M., SCHLINDWEIN, M.N., VIVIANI, V.R. Survey of Bioluminescent Coleoptera in the Atlantic Rain Forest of Serra da Paranapiacaba in São Paulo State (Brazil). Biota Neotropica. 16(1): e0045. http://dx.doi.org/10.1590/1676-0611-BN-2015-0045

\begin{abstract}
Brazil is the country with the largest number of bioluminescent beetle species in the world. However, estimates suggest that this number could much be higher, since many species remain to be discovered. In this work we made a survey of the species of bioluminescent beetles in Serra de Paranapiacaba - the largest remnant of Atlantic Forest in São Paulo State. The survey was done at Intervales State Park, Carlos Botelho State Park and municipality of Tapiraí and the following species were collected: Aspisoma lineatum, Aspisoma physonotum, Aspisoma fenestrata, Cratomorphus besckey, Cratomorphus distinctus, Photinus penai, Photinus $\mathrm{sp}_{1}$, Photinus $\mathrm{sp}_{9}$, Ethra aff. malledicta or axilaris, Ethra aff. adicta, Lucidotini incertae sedis, Cladodes flabellicornis, Cladodes demoulini, Amydetes lucernuta, Bicellonycha $\mathrm{sp}_{8}$, Bicellonycha ornaticollis, Pyrogaster lunifer, Pyrogaster moestus, Pyrogaster $\mathrm{sp}_{2}$, Pyrogaster $\mathrm{sp}_{5}$, Pyrogaster $\mathrm{sp}_{6}$, Photuris lugubris, Photuris $\mathrm{sp}_{1}$, Photuris $\mathrm{sp}_{7}$, Stenophrixotrix $\mathrm{sp}_{1}$, Brasilocerus $\mathrm{sp}_{1}$, Pseudophengodes $\mathrm{sp}_{1}$, Hapsodrilus pyrotis, Hypsiophtalmus $\mathrm{sp}_{1}$, Ptesimopsia luculenta, Pyroptesis cincticollis, Pyrearinus brevicolis, Pyrearinus candelarius, Pyrearinus micatus, Pyrophorus divergens. Our data show that Serra de Paranapiacaba is the second richest area in São Paulo state, especially in elaterids, with unique species typical of this area and species common to other investigated sites such as the Biological Station of Boracéia (in Salesópolis county) and the urbanized areas in the between Campinas - Sorocaba- São Paulo, originally covered to the Atlantic Rainforest.

Keywords: Lampyridae, Phengodidae, Elateridae, Elateroidea, Staphylinidae, bioluminescence, Fireflies, Atlantic Rainforest.
\end{abstract}

SANTOS, R.M., SCHLINDWEIN, M.N., VIVIANI, V.R. Levantamento de Coleópteros bioluminescentes na Mata Atlantica da Serra da Paranapiacaba. Biota Neotropica. 16(1): e0045. http://dx.doi.org/10.1590/16760611-BN-2015-0045

Resumo: O Brasil é o país que possui o maior número de espécies de coleópteros bioluminescentes no mundo. Entretanto, estimativas sugerem que este número possa ser bem maior, dado que muitas espécies ainda não foram descritas. Neste trabalho foi realizado um levantamento das espécies de coleópteros bioluminescentes em três localidades na Serra da Paranapiacaba - a maior área remanescente contígua de Mata Atlântica no país, com associação ao respectivo habitat. No Parque Estadual Intervales, Parque Estadual Carlos Botelho e Tapiraí foram coletadas as seguintes espécies: (Lampyidae) Aspisoma lineatum, Aspisoma physonotum, Aspisoma fenestrata, Cratomorphus besckey, Cratomorphus distinctus, Photinus penai, Photinus $\mathrm{sp}_{1}$, Photinus $\mathrm{sp}_{9}$, Ethra aff. malledicta ou axilaris, Ethra aff. adicta, Lucidotini incertae sedis, Cladodes flabellicornis, Cladodes demoulini, Amydetes $\mathrm{sp}_{1}$, Bicellonycha $\mathrm{sp}_{8}$, Bicellonycha ornaticollis, Pyrogaster lunifer, Pyrogaster moestus, Pyrogaster $\mathrm{sp}_{2}$, Pyrogaster $\mathrm{sp}_{5}$, Pyrogaster $\mathrm{sp}_{6}$, Photuris lugubris, Photuris $\mathrm{sp}_{1}$, Photuris $\mathrm{sp}_{7}$; (Phengodidae) Stenophrixotrix $\mathrm{sp}_{1}$, Brasilocerus $\mathrm{sp}_{2}$, Pseudophengodes $\mathrm{sp}_{1}$; (Elateridae) Hapsodrilus pyrotis, Hypsiophtalmus $\mathrm{sp}_{1}$, Ptesimopsia luculenta, Pyroptesis cincticollis, Pyrearinus brevicolis, Pyrearinus candelarius, Pyrearinus micatus, Pyrophorus divergens. Estes dados mostram que esta constitui a segunda área mais rica em espécies luminescentes do Estado de São Paulo, depois da Est. Biológica de Boracéia, especialmente em elaterídeos, com espécies únicas características destas localidades e espécies comuns à outras áreas investigadas, como as da Estação Biológica de Boracéia (Salesópolis, SP) e áreas urbanizadas no triângulo Campinas - Sorocaba São Paulo, originalmente cobertas por Mata Atlântica.

Palavras-chave: Lampyridae, Phengodidae, Elateridae, Elateroidea, Staphylinidae, vaga-lumes, bioluminescência, mata atlântica. 


\section{Introduction}

Brazil has the largest diversity of luminescent beetles in the world, about 500 described species, corresponding about $23 \%$ of described species in the world (Costa 2000; Viviani et al. 2010). These species are distributed mainly in the three main families of Elateroidea: Lampyridae, Phengodidae and Elateridae. Furthermore, two species of luminescent Staphylinidae were reported (Costa et al. 1986; Rosa 2010). These species are distributed mainly in the following biomes: Atlantic Rainforest, Cerrado (Savannah), Pantanal (Marshies) and Amazon Rainforest. Among these ecosystems, the Atlantic Rainforest is one of the richest and also most threatened ones, currently with only around $7-8 \%$ of the original cover or $11.4-16 \%$ when considering the the small woods (Ribeiro et al. 2009).

Despite their biodiversity, taxonomic and systematic studies on bioluminescent beetles in Brazil are still scarce. Detailed modern taxonomical studies are found mainly for Elateridae by Costa e collaborators (Costa et al. 1988, Costa 1971a, 1971b; 1972, 1975). However, the families Lampyridae and Phengodidae lack recent reviews and their systematics remains troublesome. Some studies on the biology and ecology were performed for some species of Elateridae (Costa 1975, Costa et al. 1988) and Phengodidae (Costa et al. 1999, Viviani \& Bechara 1997). In the family Lampyridae, bionomic studies were done for two semi-aquatic species of Aspisoma spp. (Costa et al. 1988, Viviani 1989), Aspisoma lineatum Gyllenhal, 1817 (Viviani et al., 2012), some lampyrid species of São Paulo State (Viviani 2001) and for Photuris fulvipes Blanchard 1837(Rosa 2007). Recently, the genus Amydetes was revised with the description of several new species (Da Silveira and Mermudes, 2014).

Considering the growing importance of fireflies and bioluminescent beetles as potential environmental indicators (Viviani et al. 2010), mainly for the impact of artificial night-lighting (Lloyd 2006; Viviani et al., 2010; Hagen et al., 2014), and their importance for scientific studies and in biotechnology as source of bioluminescent reagents (Viviani 2007), it is urgent to make biodiversity surveys to aid conservation and bioprospection programs.

The Atlantic Forest is, after the Amazon, the second largest forest type in South America. The last corridor of this forest is located mostly in São Paulo state, being composed of a series of protected areas with more than $17.300 \mathrm{~km}^{2}$ of forests (Galleti $\mathrm{Jr}$ et al. 2008). Considering the lack of knowledge about bioluminescent beetles in Brazil, in the nineties, and especially from 2006 we made surveys in the Atlantic rain forest. We already made lists of species occurring near the urban areas of Campinas, Rio Claro, Sorocaba and Votorantim cities in São Paulo State, which were mostly covered by seasonal Atlantic rain forest in the past (Viviani 2001, Viviani et al. 2010) and more recently about the bioluminescent species occurring in the hotspot of Biological Station of Boracéia located in the second largest remnant of Atlantic rain forest of Serra do Mar, along the coastline (Viviani \& Santos 2012).

In this study we present a first survey made from 2007-2012 in the largest and most preserved remnant of Atlantic rain forest in São Paulo State, which is located along of Serra da Paranapiacaba, including three main investigated sites: (I) Cachoeira do Chá in the municipality of Tapiraí at its Northern border; (II) Parque Carlos Botelho in the middle and (III) Parque Intervales in the Southern part.

\section{Materials and Methods}

Habitats description. The investigated sites are located in a largest continuous remnant of Atlantic rain forest along the scarp chain Serra da Paranapiacaba, which is a subdomain of the Serra do Mar scarp chain, located about $100 \mathrm{~km}$ from the coast between the hydrographic basins: Sorocaba-Médio Tietê, Paranapanema and Ribeira-Southern Shore. The main kind of forest is dense mountain ombrophyl forest (Fig.1) with the following phytophysionomic divisions: (I) mountain forest located over the mountains which include tall trees; (II) humid forest located between mountains over water bodies, which includes similar vegetation to the former habitat but with the presence of species better adapted to humid environments; (III) marshy areas at the borders of water bodies and streams which display typical grasses, and (IV) open fields surrounding the reservation or along thoroughfares opened in the forest. The following sites were investigated:

Cachoeira do Chá, Tapiraí. (2401'47.50"S - 47³429.47"W, $\mathbf{5 9 5 m}$ asl). This is a trail located along a stream at the Northern border of the large remnant, borthered by the route SP-79 and located $15 \mathrm{~km}$ from Tapiraí municipality. In this site the mountains display an escarpment ending at Ribeira River Valley.

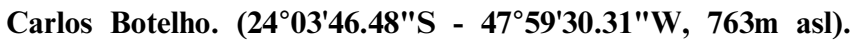
This park features a rugged terrain in the upper level followed by escarpment ending at the Ribeira River Valley in the lower part (Fig.1). Located in the north, at higher elevations there is a watershed of Ribeira River Valley Basin and another (Taquaral river) of Paranapanema River Basin. The mountains have dense rain forest (Montana forest), whereas in the lower part of the drive at the southeast, the vegetation is composed mainly by lowland tropical rain forest (Submontana forest). The survey sites within this unit are located near the headquarters, in the Northern part of the Park in the municipality of São Miguel Arcanjo.

Fazenda Intervales. (24 ${ }^{\circ} 16^{\prime} 12.46^{\prime \prime} \mathrm{S}-4^{\circ} 25^{\prime} 17.11^{\prime \prime} \mathrm{W}, 826 \mathrm{~m}$ asl). This site is located on the Serra da Paranapiacaba, and also on the Planalto de Guapiara, with very rough relief cut by headwater streams. The study site in this reserve was located between Guapiara and Ribeirão Grande municipalities. The present forest coverage is characterized as Montana forest as described above and the differential in this area is the geological and geomorphological formation, with many valleys and hills. The investigated areas were all located in the protected area, with the trails in the northwestern part of the Park.

Collecting techniques. The collecting and observations were originally done in 1991 and 1993 at Intervales, and then yearly from 2007-2012. In Intervales, collecting and observations were done in the period of October-April and eventually in July. In Carlos Botelho the observations and collecting were made weekly between July and December from 2007-2010. In Tapiraí, observations were done from 2009-2012, with sporadic visits in the same period from November through March.

Adult lampyrids and elaterids were located by their own light at night and collected in flight with entomological net, or in the bushes or in the litterfall, during the period from August to April. They were also collected on the foliage during the day, especially diurnal lampyrids. Luminescent click-beetles and even some lampyrids such as Cratomorphus distinctus Olivier 1895 firefly could also be attracted to green chemiluminescent light sticks. Adult male phengodids were collected, in rare occasions, on soil and on the grass. Firefly larvae were collected on the undergrowth, in litterfall 

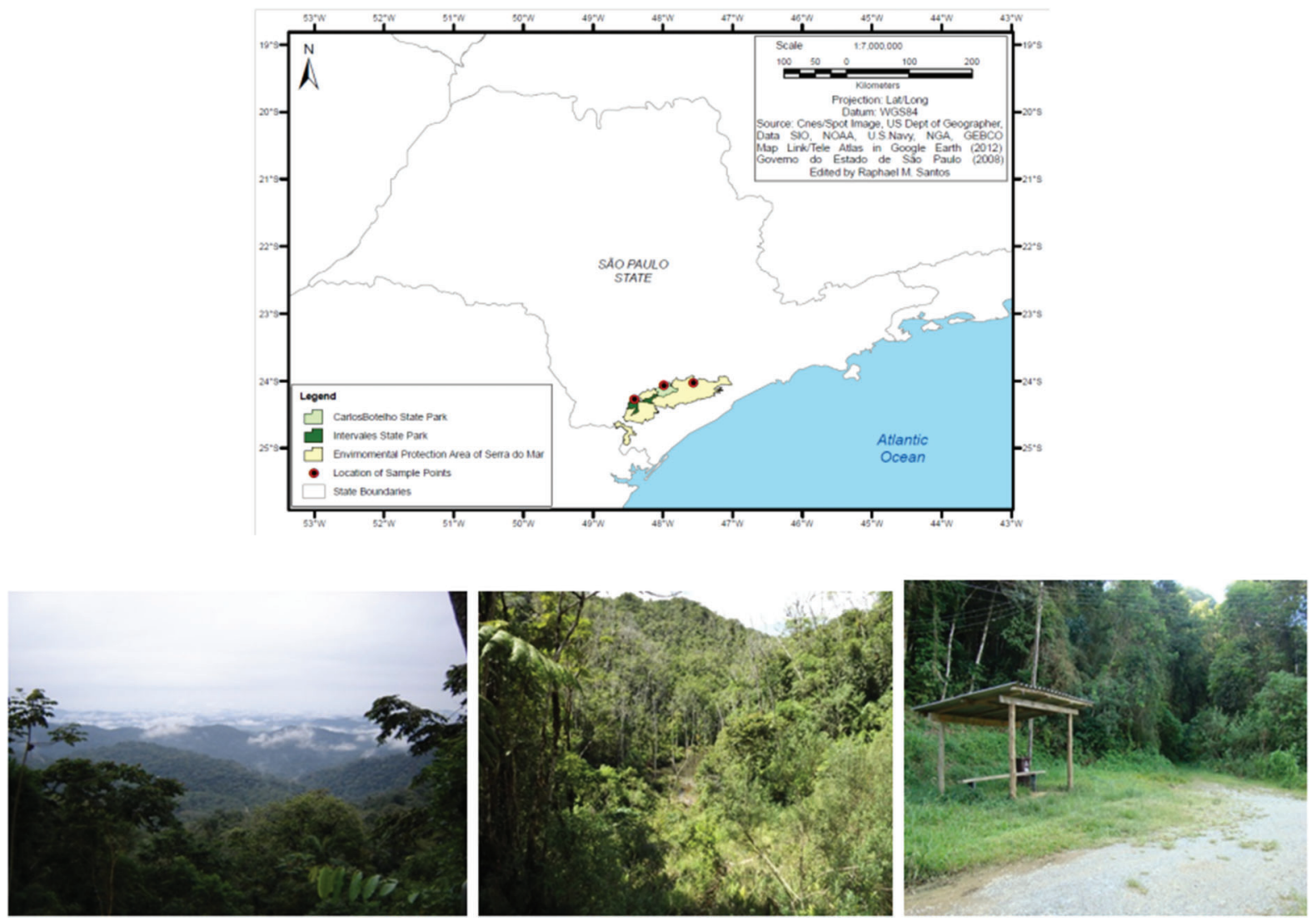

Figure 1. (Upper panel) Map of São Paulo State showing the investigated sites; (Lower panels) main vegetation types on the study area: (a) Mountain Atlantic Rainforest in the top of hills in Carlos Botelho State Park, here the view of the Submontane Forest in the Ribeira Valey Basin is shown; (b) Humid forest at Carlos Botelho State Park. View of a marshy area along riparian woods in the Taquaral stream; (c) Open field with vegetal species more light tolerant, including grasses at the ground level and creepers at the edge of woods. This image represents a site with occurrence of Bicellonycha sp8. - a brazilian synchronous firefly - in Intervales State Park.

Figura 1. (Painel superior) Mapa do Estado de São Paulo, com os pontos onde foram realizados os levantamentos; (Paineis inferiores) principais tipos de vegetação nas áreas de estudo. (a) Floresta Atlântica Montana no Parque Estadual Carlos Botelho, aqui é mostrado a vista para a Floresta Submontana no Vale do Ribeira; (b) Floresta pluvial no Parque Carlos Botelho. Vista de uma área brejosa de mata ripária no Rio Taquaral; (c) Área aberta com espécies vegetais mais tolerantes à luminosidade, como gramíneas e lianas. Esta imagem apresenta um local com ocorrência de Bicellonycha sp8 - um vagalume sincrônico brasileiro - no Parque Estadual Intervales.

and soil at night, by the location of their glows (Viviani 2001, Viviani et al. 2010). Phengodid larvae were also collected at night in the soil, in embankments, and eventually on the underbrush by location of their luminescence (Viviani \& Bechara 1997).

Identification. Specimens of fireflies and their larvae were identified first by comparison with scientific collection of Professor Viviani at UFSCar, which was previously identified by comparison with the collections of Museu de Zoologia da Universidade de São Paulo (São Paulo, Brazil), Natural History Museum of Paris (France) and British Museum (London,UK). Some species were identified by Dra. S. P. Rosa during her visit at the Natural History Museum of Paris (France). Elateridae species were previously identified by Dra. C. Costa (MZUSP) and Dra. S. P. Rosa. Several lampyrid and phengodid species could not be identified, and were catalogued by the name of the genus followed by a specific number (separated in morph species), according to Viviani \& Bechara (1997) and Viviani (2001). The specimens were deposited in the collection in UFSCar under curatorship of V. Viviani.

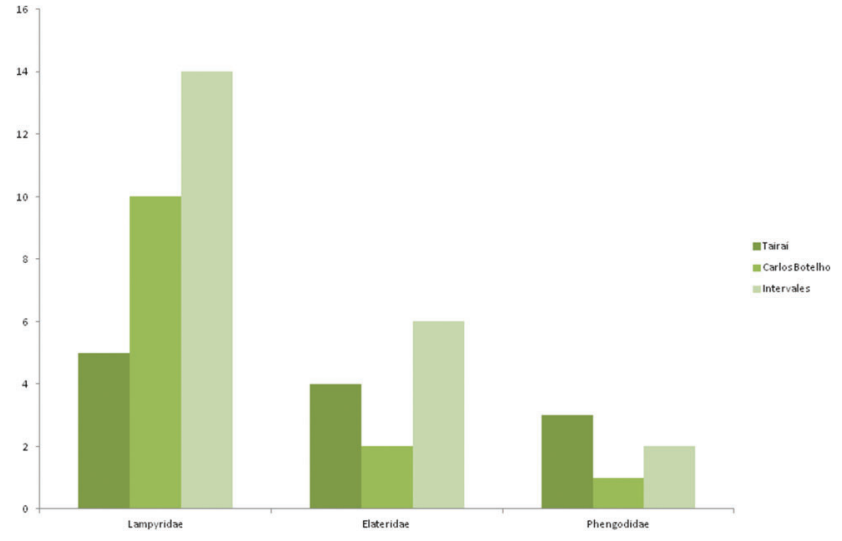

Figure 2. Number of bioluminescent Coleoptera species of different families in each site ofthe Serra da Paranapiacaba.

Figura 2. Número de espécies de coleopteros bioluminescentes por família em cada local de coletas e observações na Serra da Paranapiacaba. 
Table 1. Species of bioluminescent beetles collected in the three different sites of Serra de Paranapiacaba.

Tabela 1. Espécies de besouros bioluminescentes coletados nas três localidades de estudo na Serra de Paranapiacaba.

\begin{tabular}{|c|c|c|c|c|}
\hline Taxon & Tapiraí & PECB & PE Intervales & Reference collection \\
\hline \multicolumn{5}{|l|}{ Lampyridae } \\
\hline \multicolumn{5}{|l|}{ Cratomorphini } \\
\hline Aspisoma lineatum Gyllenhal & & $o k(4)$ & & Col. MZUSP \\
\hline Aspisoma physonotum Gorham, 1884 & & & ok $(2,3)$ & Col. MZUSP \\
\hline Aspisoma $\mathrm{sp} 2$ & ok $(1,2)$ & & ok $(1,2)$ & Col. V. Viviani \\
\hline Cratomorphus besckei Olivier 1895 & $o k(2)$ & & $o k(2)$ & Col. MZUSP \\
\hline Cratomorphus giganteus Druty, 1782 & ok (1) & $o k(1)$ & $o k(1)$ & Col. MZUSP \\
\hline \multicolumn{5}{|l|}{ Photinini } \\
\hline Photinoides jenai McDormott, 1963 & $o k^{*}(1,2,3,4)$ & ok $(1,2,3,4)$ & ok $(1,2,3,4)$ & Col. MZUSP \\
\hline Photinus $\mathrm{sp}_{1}$ & & ok (1) & $o k(1)$ & Col. V. Viviani \\
\hline Photinus $\mathrm{sp}_{9}$ & $o k(2)$ & & & Col. V. Viviani \\
\hline \multicolumn{5}{|l|}{ Lucidotini } \\
\hline Ethra aff. malledicta or axilaris & & $o k(1)$ & & $*$ \\
\hline Ethra aff. adicta & & & $o k(1)$ & $*$ \\
\hline \multicolumn{5}{|l|}{ Lamprocerini } \\
\hline Cladodes demoulini & & & $o k(1)$ & Col. MZUSP \\
\hline Cladodes flabellicornis & & $o k(1)$ & & Col. V. Viviani \\
\hline \multicolumn{5}{|l|}{ Amydetinae } \\
\hline Amydetes lucernuta & & & $o k(4)$ & - \\
\hline \multicolumn{5}{|l|}{ Photurinae } \\
\hline Bicellonycha sp. & & $o k(3,4)$ & & - \\
\hline Bicellonycha $\mathrm{sp}_{8}$ & $o k^{*}(3,4)$ & & ok $(3,4)$ & Col. V. Viviani \\
\hline Pyrogaster lunifer Eschscholtz, 1822 & & $o k(1)$ & & Col. V. Viviani \\
\hline Pyrogaster moestus Germar 1824 & & ok $(1,2)$ & ok $(1,2)$ & Col. V. Viviani \\
\hline Pyrogaster $\mathrm{sp}_{3}$ & & & $o k(1)$ & PORTO (2011) \\
\hline Photuris lugubris Gorham 1881 & & ok $(1,2)$ & ok $(1,2)$ & Col. V. Viviani \\
\hline Photuris $\mathrm{sp}_{7}$ & & & $o k(1)$ & Col. V. Viviani \\
\hline \multicolumn{5}{|l|}{ Phengodidae } \\
\hline \multicolumn{5}{|l|}{ Mastinocerini } \\
\hline Stenophrixotrix $\mathrm{sp}_{1}$ & $o k(1)$ & $o k(1)$ & $o k(1)$ & Col. V. Viviani \\
\hline Brasilocerus $\mathrm{sp}_{1}$ & ok $(1,2)$ & & & - \\
\hline Phrixotrix hirtus Olivier, 1909 & $o k^{*}(2)$ & & & Col. V. Viviani \\
\hline \multicolumn{5}{|l|}{ Phengodini } \\
\hline Pseudophengodes $\mathrm{sp}_{1}$ & & & ok $(1,2)$ & - \\
\hline \multicolumn{5}{|l|}{ Elateridae } \\
\hline \multicolumn{5}{|l|}{ Agrypininae/Pyrophorini } \\
\hline Hapsodrilus pyrotis Germar, 1841 & $o k(1)$ & & $o k(1)$ & Col. MZUSP \\
\hline Pyroptesis cincticollis Germar 1841 & ok $(1,3)$ & & ok $(1,3)$ & Col. MZUSP \\
\hline Ptesimopsia luculenta Germar, 1841 & & & ok $(1,2)$ & Col. MZUSP \\
\hline Pyrearinus brevicollis Eschsdioltz 1829 & & $o k(1)$ & & Col. MZUSP \\
\hline Pyrearinus candelarius Germar 1841 & & & $o k(1)$ & Col. V. Viviani \\
\hline Pyrearinus micatus Costa 1978 & ok $(1,2)$ & & ok $(1,2)$ & Col. V. Viviani \\
\hline Pyrophorus divergens Eschscholtz 1829 & $o k(1)$ & $o k(1)$ & $o k(1)$ & Col. V. Viviani \\
\hline
\end{tabular}

Legenda: ok = ocorrência; $o k^{*}=$ ocorrência mas sem material fixado; (1) = floresta Montana; (2) = floresta úmida; (3) = áreas brejosas; (4) = áreas abertas. ** identificação pela chave.

Legend: ok = collected; $o k^{*}=$ occurence recorded but no fixed material; (1) = montane forest; $(2)=$ umid forest; (3) = marshy areas; (4) = open field. ** identificação pela chave.

\section{Results and Discussion}

Taxonomic survey. Thirty one species of luminescent beetles were cataloged in the Serra da Paranapiacaba: 20 Lampyidae, 7 Elateridae, 4 Phengodidae and 1 Staphylinidae (Table 1).

The richness of each family of luminous beetles in each conservation unit is summarized in Figure 2.

Lampyridae (Fig. 3). The number of observed lampyrid species was 10 in Carlos Botelho and 14 in the Intervales.
In Tapiraí only five species were found (see Table 1). The smaller number found in Tapiraí could be due to the lower frequency and smaller scanned area of collecting made in this site. The following species were unique to Carlos Botelho: Aspisoma lineatum, Photinus $\mathrm{sp}_{1}$, Ethra aff maledicta or axillaris, Lucidotini incertae sedis, Cladodes flabellicornis, Pyrogaster lunifer, Pyrogaster $\mathrm{sp}_{5}$ and Pyrogaster $\mathrm{sp}_{6}$. Seven species were found at Intervales but were not been found in Carlos Botelho and Tapiraí: Aspisoma physonotum, Aspisoma fenestrata, Amydetes lucernuta, Bicellonychia ornaticollis, Pyrogaster moestus, Photuris $\mathrm{sp}_{1}$ and Photuris $\mathrm{sp}_{7}$. 


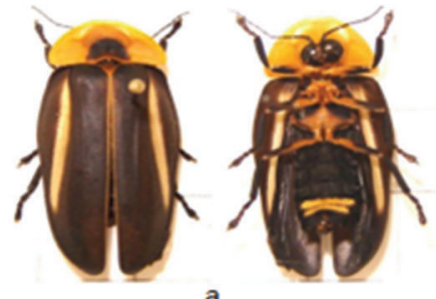

a

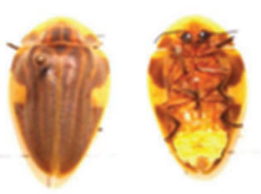

c
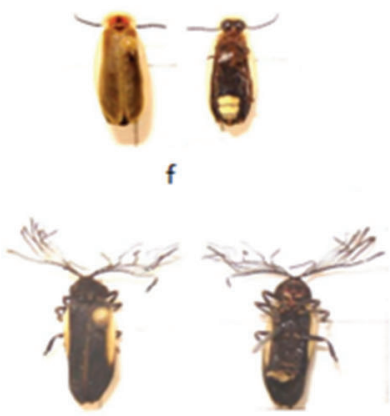

i

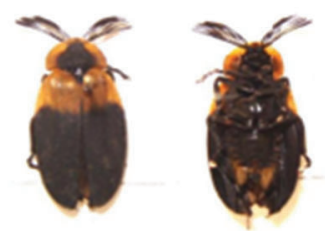

k
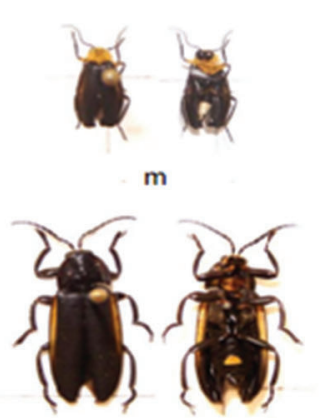

p

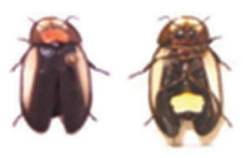

b

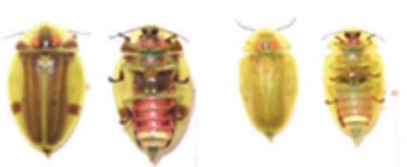

d

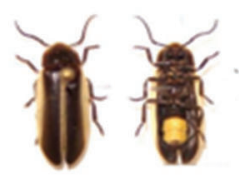

g

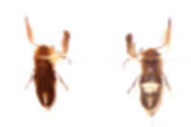

j

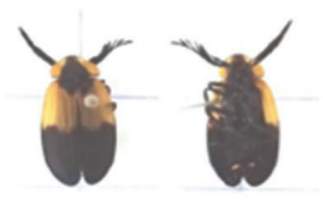

I
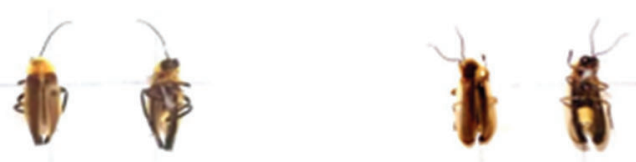

o

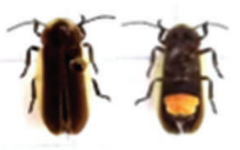

h $1 \mathrm{~cm}$

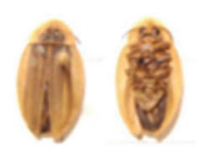

e

.



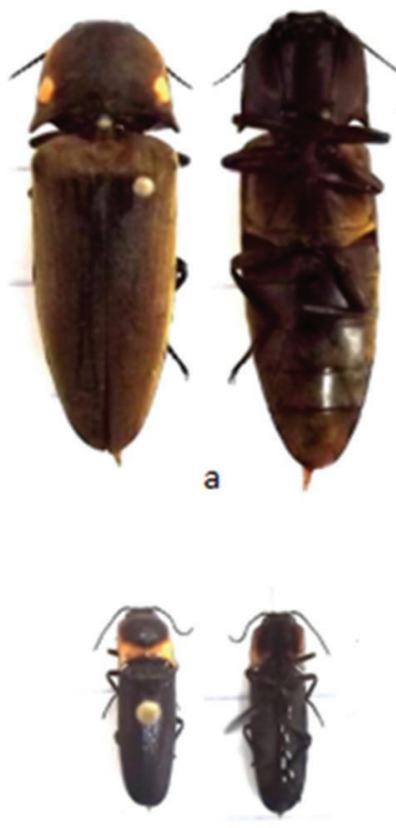

C
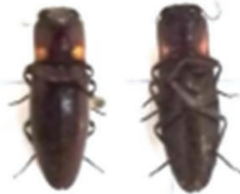

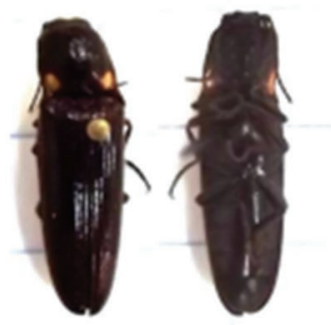

b

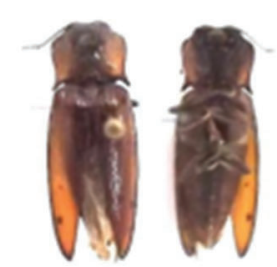

d

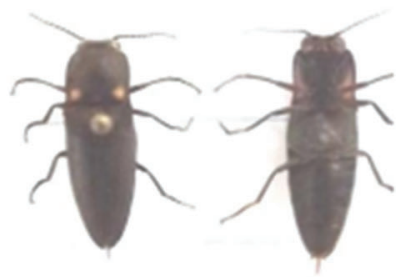

e

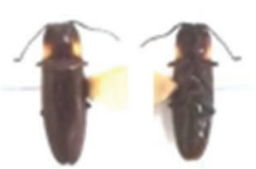

f

Figure 4. Bioluminescent click-beetles of SA de Paranapiacaba: (a) Pyrophorus divergens; (b) Ptesimopsia luculenta; (c) Ptesimopsia cincticollis; (d) Pyrearinus candelarius; (e) Pyrearinus micatus, (f) Pyrearinus brevicollis; (g) Hapsodrilus pyrotis.

Figura 4. Elaterideos bioluminescentes da SA de Paranapiacaba: (a) Pyrophorus divergens; (b) Ptesimopsia luculenta; (c) Ptesimopsia cincticollis; (d) Pyrearinus candelarius; (e) Pyrearinus micatus, (f) Pyrearinus brevicollis; (g) Hapsodrilus pyrotis.

found. In Tapiraí Brasilocerus $\mathrm{sp}_{2}$ and Phrixotrix hirtus were found and in Intervales Pseudophengodes $\mathrm{sp}_{1}$. The arboreal Stenophrixotrix $\mathrm{sp}_{1}$ was common to all three areas. When compared with Boraceia, the number of species and abundance of phengodids was lower. The following species were found in both places: Brasilocerus sp2, Phrixotrix hirtus and Stenophrixotrix.

Elateridae (Fig. 4). The studied area was especially rich in luminescent click-beetles, with eight species: Hapsodrilus pyrotis Germar 1841, Hypsiophtalmus $\mathrm{sp}_{1}$, Ptesimopsia luculenta, Pyrearinus brevicollis, Pyrearinus candelarius, Pyrearinus micatus, Pyrearinus sp., Pyrophorus divergens. All these species were found at Intervales.

In Tapiraí, four species of bioluminescent click-beetles were found: Pyrophorus divergens, Hypsiophtalmus $\mathrm{sp}_{1}$, Pyrearinus micatus and Pyrearinus meatus: The species Hapsodrylus pyrotis, Ptesimopsia luculenta and Pyrearinus candelarius were not observed in Tapiraí and Carlos Botelho. Comparatively, Boraceia Biological Station showed only three species (Pyrophorus divergens, Pyrearinus micatus and Hapsodrilus pyrotis) and the municipalites of Campinas and Sorocaba four species (Hapsodrilus ignifer, Pyrearinus candelarius, Pyrearinus micatus and Pyrophorus divergens).
Considering that the surveys were conducted in the same morphoclimatic domain and continuous geographic Mountain Tropical Rain Forest, it was surprising that several of these species were not found more widely distributed among these areas. This could be due to two reasons: (1) there is more heterogeneity in the habitats than assumed, and the same kind of specific habitats were not sampled in the three localities, or (2) because the survey was not conducted simultaneously in the three areas. In this case, the seasonality of adults of a given species may vary between areas.

Comparison with other sites of Atlantic forest. When comparing this survey to Biol. St. of Boraceía, which is the second largest remnant of Atlantic Rainforest in São Paulo State, Paranapiacaba remnant showed a slightly smaller biodiversity. The following species were found in common in these two sites: Aspisoma physonotum Gorham 1884, Cratomorphus besckei Olivier 1895, Cratomorphus distinctus Olivier 1895, Photinus penai Germar 1824, Cladodes flabellicornis Motsch 1853, Pyrogaster moestus Germar 1824, Pyrogaster $\mathrm{sp}_{2}$, Photuris lugubris Gorham 1881, Photuris $\mathrm{sp}_{7}$, Haspodrilus pyrotis Germar 1841, Pyrophorus divergens Eschsholtz 1829 and Pyrearinus micatus Costa 1978. Paranapiacaba forests were especially rich in 


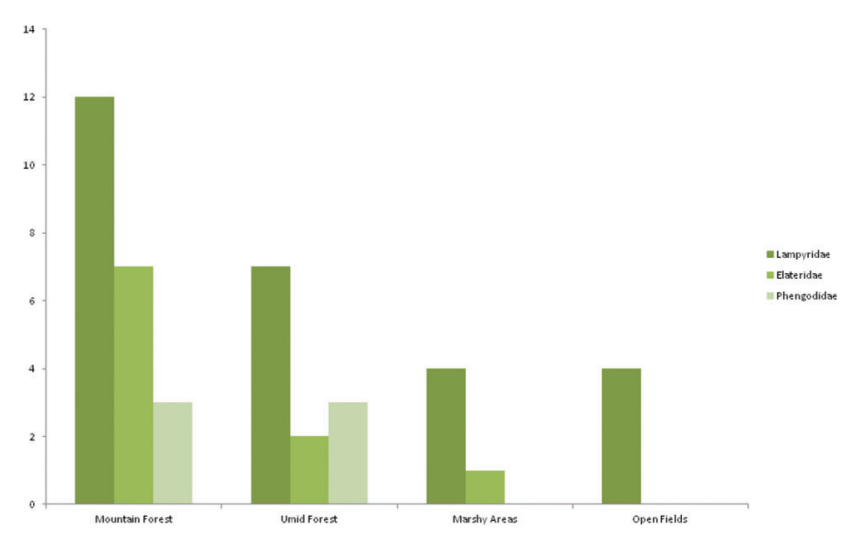

Figure 5. Distribution per habitat of the main families of bioluminescent beetles in Serra da Paranapiacaba.

Figura 5. Distribuição por habitats de familias de besouros bioluminescentes da Serra de Paranapiacaba.

elaterids, whereas Boracéia was richer in fireflies. When compared with the fragmented remnants of the semi-seasonal forests and secondary growths of urbanized areas of Campinas, Sorocaba and Rio Claro municipalities, only the following species were found in common: Aspisoma lineatum, Aspisoma physonotum Gorham 1884, Cratomorphus distinctus Olivier 1895, Photinus $\mathrm{sp}_{1}$, Photinus $\mathrm{sp}_{2}$, Amydetes lucernuta, Bicellonycha ornaticollis Blanch, Pyrogaster moestus Germar 1824, Photuris $\mathrm{sp}_{7}$, Pyrearinus micatus Costa 1978 and Pyrophorus divergens Eschsholtz 1829. Thus, the species: Aspisoma fenestrata, Ethra aff maledicta or axillaris, Bicellonycha $\mathrm{sp}_{8}$, Pyrogaster lunifer Eschsholtz., Photuris $\mathrm{sp}_{1}$, Brasilocerus $\mathrm{sp}_{2}$, Hypsiophtalmus $\mathrm{sp}_{1}$, Ptesimopsia luculenta, Pyrearinus brevicolis and Pyrearinus $\mathrm{sp}_{1}$ were apparently unique to Paranapiacaba forests.

The frequency of species per family in places where they are visibly more abundant is shown on Fig. 5. There is an apparent trend for greater richness for all families in Mountain Forest. More refined analysis with quantification of abundance is however required, to confirm whether the diversity of habitats is significant or not. Marshy areas seem to harbor a lower number of species.

\section{Conclusions}

The Serra de Paranapiacaba displays the second largest diversity of luminescent beetles in the Atlantic rain forest morphoclimatic domain of São Paulo state, with 34 species. Some species are common to sampled areas of semi-seasonal forest close to urbanized areas of inner São Paulo state and to the second largest and most preserved area of Biological Station of Boracéia. This area is especially rich in elaterid luminescent beetles, but displays poorer diversity of Phengodidae.

\section{Acknowledgements}

We are grateful to Dra. Simone Policena Rosa (MZUSP) for the identification of the specimens to Édipo F. V. da Silva and Pedro R. Busana (UFSCar) for assistance in the field activities and to Conselho Nacional de Desenvolvimento Científico e Tecnológico (CNPq) and Biota Project - FAPESP (Proc. 2011/19427-9) for financial support.

\section{References}

COSTA, C. 1971. Gênero Pyrophorus. 4. Redescrição e revalidação de Pyrophorus divergens Eschsholtz (Coleoptera, Elateridae). Papéis Avulsos Zool., V.24(4):65-72.

COSTA, C. 1971. Gênero Pyrophorus. 5. Redescrição de Pyrophorus ignitus (Fabricius) (Col., Elateridae). Papéis Avulsos Zool., 24(7): 113-116.

COSTA, C. 1971. Gênero Pyrophorus. 6. Redescrição de P. tuberculifer Eschsholtz, P. phosphorecens Castelnau e descrição de quatorze espécies novas (Col. Elateridae). Papéis Avulsos Zool., V. 25(21): 199-227.

COSTA, C. 1975. Systematics and evolution of the tribes Pyrophorini and Heligmini with description of Campyloxeninae, a new subfamily. Arquivos Zoologia, 2, pp. 49-190, http://dx.doi.org/10.11606/issn.21767793.v26i2p49-190.

COSTA, C. 2000. Estado de Conocimiento de los Coleoptera Neotropicales. PRIBES, Zaragoza, Spain. (F. Martin-Pera, J.J. Morrone, \& A. Melic, Eds.) Zaragoza, Spain: PRIBES

COSTA, C., VANIN, S.A. \& CASARI-CHEN, S. 1988. Larvas de Coleoptera do Brasil. São Paulo: Museu de Zoologia (Universidade de São Paulo), http://dx.doi.org/10.5962/bhl.title.100233.

COSTA, C., VANIN, S.A. \& VIVIANI, V.R. 1999. Larvae of Neotropical Coleoptera. XXVII. Phrixotrix hirtus Olivier, 1909, Descriptions of Immatures neotenic female, adult male and bionomic data (Phengodinae, Phengodidae, Coleoptera). Ilheringia. Ser. Zool. (86):9-28.

COSTA, C., VANIN, S. \& COLEOPICOLO NETO, P. 1986. Larvae of Neotropical Coleoptera XIV: First record of bioluminescence in the family Staphylinidae (Xantholini). Revista Brasileira de Entomologia (30):101-104.

DA SILVEIRA, L.F. \& MERMUDES, J.R.M. 2014. Systematic review of the firefy genus Amydetes Illiger, 1807 (Coleoptera: Lampyridae), with description of 13 new species. Zootaxa. 3765(3):201-248, http://dx.doi.org/10.11646/zootaxa.3765.3.1.

GALLETI JR, P.M., RODRIGUES, F.P., SOLÉ-CAVA, A.M., MIYAKI, C.Y., CARVALHO, D., EIZIRIK, E. et al. 2008. Genética da conservação na biodiversidade brasileira. In: R. Frankham, J.D. Ballou, \& D.A. Briscoe, Fundamentos de genética da Conservação (pp. 199-229). Ribeirão Preto, SP: Editora SBG, 280p.

HAGEN O, SANTOS, R.M., SCHLINDWEIN, M.N., VIVIANI, V.R. 2014. Artificial Night Lighting Reduces Firefly (Coleoptera: Lampyridae) Occurrence in Sorocaba, Brazil. Adv. in Entomol, 3: 24-32. 2015, http://dx.doi.org/10.4236/ae.2015.31004.

LLOYD, J.E. 2006. Stray Light, fireflies and fireflyers. In: C. Rich, \& T. Longcore, Ecological Consequences of Artificial Night Lighting (pp. 345-364). Washington DC.: Island Press.

RIBEIRO, M.C., METZGER, J.P., MARTENSEN, A.C., PONZONI, F.J., HIROTA, M.M. 2009. The Brazilian Atlântic Forest: How much is left, and how is the remaining forest distribuited? Implications for conservation. Biological Conservation, 142(6):1141-1153, http://dx.doi. org/10.1016/j.biocon.2009.02.021.

ROSA, S.P. 2007. Description of Photuris fulvipes Blanchard immatures (Coleoptera: Lampyridae, Photurinae) and bionomic aspects under laboratory conditions. Revista Brasileira de Entomologia, 2(51):125-130, http://dx.doi.org/10.1590/S0085-56262007000200001.

VIVIANI, V.R. 1989. Descricão dos estágios imaturos e dados biológicos de Aspisoma sp. (Coleoptera: Lampyridae). Revista Brasileira de Entomologia, 2(33):359-366.

VIVIANI, V.R. 2001. Fireflies (Coleoptera: Lampyridae) from Southeastern Brazil:Habitats, Life History, and Bioluminescence. Ann. Entomol. Soc. Am., 1(94):129-145, http://dx.doi.org/10.1603/00138746(2001)094[0129:FCLFSB]2.0.CO;2.

VIVIANI, V.R. 2007. Luciferases de vagalumes. Biotecnologia e Desenvolvimento, (37):8-19.

VIVIANI, V.R. \& BECHARA, E.J. 1997. Bioluminescence and biological aspects of Brazilian railroadworms (Coleoptera: Phengodidae). 
Santos R. M. et al.

Ann. Entom. Soc. Am., 3(90):389-398, http://dx.doi.org/10.1093/aesa/ 90.3.389.

VIVIANI, V.R., ROCHA, M.Y. \& HAGEN, O. 2010. Fauna de besouros bioluminescentes (Coleoptera: Elateroidea: Lampyridae, Phengodidae, Elaetridae) nos municípios de Campinas, Sorocaba-Votorantim e Rio Claro-Limeira (SP, Brasil). Biota
Neotropica, 10(2), http://dx.doi.org/10.1590/S1676-06032010000200 013.

VIVIANI, V.R., ROSA, S.P., MARTINS, M.A. 2012. Aspisoma lineatum (Gyllenhal) (Coleoptera: Lampyridae) firefly: description of the immatures, biological and ecological aspects. Neotropical Entomol. 41:1-6, http://dx.doi.org/10.1007/s13744-011-0006-8.

Received 21/04/2015

Revised 16/10/2015

Accepted 28/10/2015 